\title{
TACITUS SE ANNALES I.1: 'N NARRATOLOGIESE ANALISE
}

A. Kotzé, Departement Latyn, Universiteit van Stellenbosch

\section{INLEIDEND}

Dat Tacitus se geskiedskrywing behoort tot 'n eiesoortige letterkundige genre wat optimaal aan die hand van literêre metodes ondersoek kan word, is 'n feit wat toenemend deur klassici as onomstrede aanvaar word. Opmerkings soos dié deur Wellesley (1987:450) toon egter dat die navorser wat Tacitus se Annales suiwer literêr wil benader, steeds sy invalshoek en werkwyse moet verdedig of ten minste duidelik moet omskryf:

It must be questioned whether at this date the purely literary critic such as Aubrion can contribute greatly to a better understanding of Tacitus as historian.

(Wellesley 1987:450)

Die doel en aard van antieke geskiedskrywing plaas dit nader aan wat vandag algemeen onder die konsep "letterkunde" as onder die konsep "geskiedenis" verstaan word.1 Die navorsing wat moet bydra tot 'n beter begrip van Tacitus se Annales kan dus nie beskou word as die uitsluitlike taak van die historikus nie. Die letterkundige en die historikus moet hand aan hand werk. Dit is egter nie die historikus wat deur middel van die daarstel van 'n objektiewe stel gegewens ("dit wat werklik gebeur het") vir die letterkundige 'n maatstaf in die hand gee waaraan hy die meriete van Tacitus se werk kan meet nie. Dit is die letterkundige wat met al sy kennis van antieke letterkundige genres en praktyke moet probeer vasstel wat Tacitus in sy letterkundige werk oor die geskiedenis wil sê. Die literêre kritikus kan die historiese instelling wat in die Annales weerspieäl word met literêre metodes ondersoek en neerskryf. Dit kan die historikus dan as nog 'n stel gegewens integreer in die beeld van die antieke wêreld wat hy uit verskillende bronne probeer saamstel.

\section{TACITUS SE GESKIEDSKRYWING EN DIE NARRATOLOGIE}

As aanvaar word dat Tacitus se geskiedskrywing sinvol aan die hand van literêre metodes ondersoek kan word, is dit nog nie vanselfsprekend dat juis die narratologie 'n geskikte invalshoek bied nie. Hierdie artikel hoop om aan te toon dat laasgenoemde wel die geval is.

Vervolgens word eerstens enkele probleme rondom die implementering van moderne literêr-teoreties begronde metodes soos die narratologie aangedui. Tweedens word aandag gegee aan die narratologiese onderskeiding tussen die verskillende vlakke binne 'n verhalende teks en die lig wat hierdie onderskeiding werp op die ou polemiek rondom Tacitus se geskiedskrywing. (Hieruit behoort reeds te blyk dat die terme en kategorieë van die narratologie besonder nuttige instrumente ook in die hand van die Tacitus-navorser kan wees.) Derdens volg 'n analise van Annales I.1, voorafgegaan deur 'n omskrywing van slegs dié narratologiese terme wat in die analise ter sprake kom.

1 Vir 'n volledige bespreking hiervan, vgl. Kotzé (1990:7-14). 


\subsection{Enkele probleme}

Een van die belangrikste besware teen die gebruik van literêr-teoreties begronde metodes hang saam met die veelvoud van studies op hierdie gebied oor die afgelope dekades. Die insigte van die navorsingsveld is nog nie gekonsolideer nie. Wat spesifiek die narratologie betref: enersyds bestaan daar selfs oor sommige basiese begrippe en terme nog nie eenstemmigheid nie; andersyds sou 'n strukturalistiese metode soos die narratologie reeds as verouderd beskou kon word. Rimmon-Kenan (1983:130) se samevatting van hierdie dilemma (en haar positiewe gevolgtrekking oor die bruikbaarheid van die narratologie) is steeds van toepassing:

In many circles, including some universities, the poetics of narrative fiction is either ignored or treated with suspicion. . . . In other circles, this discipline is already considered dead or at least superseded by deconstruction. . . . And yet the poetics of narrative fiction is neither the newborn babe it may seem to the former nor the corpse it may seem to the latter. The discipline is still alive and kicking, although (or perhaps because) it no longer enjoys the privilege of the latest fashion.

My voorlopige navorsing het getoon dat die moontlikhede wat die narratologie die Tacitusnavorser bied so waardevol is dat dit 'n worsteling met genoemde (en ander) probleme regverdig. Die narratologie (veral in sy onderskeiding van verskillende vlakke in 'n verhalende teks) maak byvoorbeeld 'n besonder noukeurige omskrywing van die doel en aard van Tacitus se antieke geskiedskrywing moontlik.

\subsection{Vier vlakke van die verhaiende teks}

Wanneer 'n vertelling (narrative) soos dié in die Annales van nader beskou word, word dit duidelik dat daar vier verskillende vlakke of wêrelde betrokke is. ${ }^{2}$ Die vier vlakke word hier in navolging van Brink (1987:39-41) met die terme "vertelteks", "storie", "vertelproses" en "geskiedenis" aangedui. Bespreking van die terme word beperk tot wat noodsaaklik is vir die argumente en analise voor hande. 3

Die vertelteks is dit wat die leser voor hom het, die eindige gestruktureerde geheel van taaltekens. Deur dié medium verkry hy toegang tot die storie wat vertel word. "Hierdie medium is nie net die taal nie, maar die hele manier waarop die storie in die boek aan my vertel word" (Brink 1987:39), dit wil se ook stilistiese figure, die struktuur van die verhaal en so meer.

Storie word deur Brink (1987:39-40) soos volg gedefinieer:

En eintlik is die storie dus die resultaat van daardie teks wat ek gelees het. . . . Dit verteenwoordig die leser se konstruksie van 'n gegewe met ' $n$ begin, ' $n$ middel en 'n einde, opgebou volgens die logiese, chronologiese en kousale patrone wat daardie leser uit sy eie belewenis van die wêreld ken. Die vertelteks kan by die end

2 Baie literêre teoretici onderskei slegs 3 verskillende vlakke. Vgl. Kotzé (1990: 18).

3 Vir 'n meer volledige bespreking, vgl. Kotzé (1990:18-22). 
van 'n storie begin en daarvandaan na die begin teruggaan ... . maar in die leser se konstruksie van die storie . . . word alles . . . op hul "natuurlike" plekke in die handelingsverloop geplaas.

In die vertelteks van die Annales word byvoorbeeld in 1.9 gegewens oor Augustus se regering deur 'n sekondêre woordvoerder verskaf (non regno tamen neque dictatura, sed principis nomine constitutam rem publicam). 4 Dit is addisionele inligting oor Augustus se bewindsoorname wat in 1.2 tot $\mathbf{I . 4}$ kortliks afgehandel is. In 1.5 is reeds vertel dat Tiberius die bewind oorgeneem het. Die weergee van hierdie inligting oor Augustus in I.9 (dit wil sê te midde van die vertelling oor Tiberius) is geregverdig en funksioneel. Dit beinvloed die manier waarop die leser die storie hier konstrueer. Nogtans vorm hierdie gegewens in die storie wat die leser konstrueer, deel van sy voorstelling van hoe Augustus aan bewind gekom en regeer het: die "natuurlike" plek van die gegewens in die handelingsverloop.

Die derde laag wat in die verhalende teks onderskei word, is die vertelproses. Die term "vertelproses" verwys na tekens in die vertelteks wat heenwys na die verteller en sy proses van vertelling, dit wil sê "die hele kompleks waardeur 'n vertelteks tot stand kom en weer gedekodeer word" (Brink 1987:40). Dit is op hierdie vlak waar die terme implisiete outeur (verteller) en leser ter sprake kom.5

Die belangrikste onderskeid vir die huidige bespreking is die tussen storie en die vierde vlak van die verhalende teks, naamlik geskiedenis. Waar storie as die resultaat van die vertelling gedefinieer is, kan geskiedenis as die ander uiterste van die spektrum beskou word. Storie is die eindpunt van die vertelling. Geskiedenis is die beginpunt daarvan:

Die vertelproses begin met 'n geskiedenis, waarby ons dan kan dink aan 'n konsep, 'n idee, 'n rudimentêre gegewe waarin daar sekere impulse bestaan wat uitgewerk en gedetailleer kan word tot karakters en gebeurtenisse binne 'n konteks van ruimte en tyd kortom, tot wat uiteindelik as 'n storie uit die vertelteks gehaal sal kan word.

(Brink 1987:41)

In bogenoemde opmerkings rondom die begrip "geskiedenis" is perspektiewe vervat wat van kardinale belang vir die debat rondom Tacitus se geskiedskrywing is. Die rudimentêre gegewe wat die beginpunt vir die vertelling in die Annales vorm, is die geskiedenis (in die onspesifieke, nie-vertelkundige sin van hierdie woord) van die Romeinse volk. Wanneer so 'n vertelling ontleed word met die uitsluitlike doel om die geskiedenis (beide die algemene en die narratologiese betekenisse van die woord het betrekking) te rekonstrueer, is daar probleme wat deeglik in berekening gebring moet word.

Eerstens maak die aard van taal en menslike kommunikasie dit onwaarskynlik dat "wat die verteller aan die duskant van die vertelaksie enkodeer, presies dieselfde is (of in ideale omstandighede presies dieselfde kan wees) as wat aan die ander uiteinde van die kommunikasiedaad gedekodeer word" (Brink 1987:40-41). Nog belangriker is dat die hedendaagse leser van antieke geskiedskrywing homself moet losmaak van die verwagtinge waarmee hy geleer het om (eietydse) geskiedenis te lees. Hy moet besef dat by antieke geskiedskrywing dit nie die bedoeling van die verteller was om sy rudimentere gegewe op so 'n wyse in te klee en aan te bied dat sy leser die geskiedenis kan rekanstrueer soos dit werklik gebeur het nie. Hy het wel die rudimentêre gegewe so ingeklee dat die leser uit die

4 Alle teksverwysings na Heubner (1983).

5 Vgl. Kotzé (1990:20-21). 
vertelteks 'n storie kan konstrueer wat sy (die skrywer se) opinie oor die rudimentêre gegewe weerspieël.

Dit is tyd dat Tacitus se geskiedskrywing onbevange gelees word met die hoofsaaklike doel om aan te toon hoe uitmuntend Tacitus van literêre middele gebruik maak om die leser te rig in sy (die leser se) konstruksie van die storie. Hierdie storie moet dan nie meer beskou word as 'n verdraaiing van die geskiedenis nie. Dit moet noukeurig ondersoek word met die doel om vas te stel wat die oordeel is wat die verteller oor hierdie belangrike tydperk in die Romeinse geskiedenis aan sy leser/hoorder wil kommunikeer. Die hieropvolgende begripsomskrywing en analise is ' $n$ poging tot so 'n ondersoek.

\subsection{Omskrywing van kernbegrippe: storie, ruimte en storieruimte}

Die eenvoudigste formule waartoe die storie gereduseer kan word, is: "iets gebeur met iemand" (Brink 1987:38). Die twee basiese elemente van die storie wat uit die vertelteks gekonstrueer kan word, is dus gebeure en karakters. Dié twee elemente kan nie anders voorgestel word nie as teen 'n agtergrond van tyd en ruimte (Brink 1987:38). Die leser plaas elke karakter of gebeurtenis wat hy uit die vertelteks konstrueer, binne die dimensies "tyd" en "ruimte".

Beide kategoriee is in 'n mate problematies, maar waar die rol van tyd in 'n vertelling deeglik deur teoretici uitgetrap is, kry die vertelkundige kategorie "ruimte" in narratologiese modelle gewoonlik min of geen aandag nie. 6 Brink gee die redes hiervoor:

Ten eerste bestaan ruimte in die storie soos wat tyd bestaan: $n$ l. nie as 'n "element" (soos gebeurtenisse of karakters) nie, maar as 'n dimensie: maar in die vertelteks het dit nie 'n ekwivalent nie. (Die ruimte - omvang, lengte - van die teks verteenwoordig immers die tyd van die storie.) Dáár bestaan dit, soos karakters, net in die vorm van kodes, "flikkeringe van betekenis", tekens wat hénwys na 'n wêreld wat die leser self moet konstrueer. (Brink 1987:107)

Brink (1987:107-122) wy 'n hele afdeling aan ruimte in die hoofstuk genaamd "Storie: . . . in sekere omstandighede (ruimte)." Hy definieer ruimte wyer as die ander skrywers oor die narratologie:

Uitgaande van die waarneming dat die elemente van 'n storie (gebeure, figuur) optree in 'n ruimte van vertelling (d.w.s: 'n ruimte waarin daar vertel word, maar ook: 'n ruimte geskep deur vertelling), kan ons sê dat álles wat in die vertelteks gebruik word om (gewoonlik in samehang met tyd) 'n situasie te konstitueer waarbinne "iets met iemand gebeur", tot die konsep van narratiewe ruimte behoort. Dus: nie net die plek of omgewing ... waar die insidente plaasvind of waarin die karakters optree nie, maar die hele "narratiewe klimaat" daar rondom.

(Brink 1987:108)

6 Genette (1982) en Rimmon-Kenan (1983) verwys in bulle modelle glad nie na ruimte nie; Bal (1978:49-51 en 97-103) en Prince (1982:32-33, 66 en 73-74) verwys kortliks daama, maar slegs in terme van fisieke riimte. Vgl. Brink (1987:107-108) vir 'n volledige bespreking van die redes waarom ruimte dikwels afgeskeep word en die probleme daaraan verbonde. 
In die voorbeelde wat Brink bespreek om te illustreer wat hy beskou as "narratiewe klimaat", noem hy byvoorbeeld "oorlog", "vrees", en "die laatsomer self: nie (net) beleef as 'n tydperk nie maar as 'n ervaringsdimensie bepaal deur die belewing van verganklikheid". Hy sien ook sosio-ekonomiese omstandighede of mitologiese, psigologiese, filosofiese en selfs kunsteoretiese verwysingsraamwerke as deel van die ruimte vir spesifieke verhale (Brink 1987:108-109). Alles wat deel vorm van die wêreld of situasie wat die leser konstrueer en waarbinne hy in sy verbeelding die gebeure en karakters van die verhaal sien optree, vorm dus deel van die narratiewe ruimte.

Brink (1987:109) onderskei tussen drie vlakke van narratiewe ruimte. Hy noem dit vertelruimte, vertellersruimte en vertelde ruimte. Slegs wertelde ruimte is hier ter sake. Dit is ruimte op die vlak van die storie, die ruimte waarbinne die gebeure en karakters van die storie optree en wat deur die leser gekonstrueer word uit die tekens in die teks (Brink 1987:111-112). Die meegaande analise fokus tot 'n groot mate op die storievlak van die verhaal en meer spesifiek op die ruimte van die storie, hier genoem storieruimte.

Een van die belangrikste maniere om te bepaal watter oordele oor die geskiedenis Tacitus in die Annales wil oordra, is om te ondersoek hoe hy die omstandighede waarbinne dinge gebeur, die atmosfeer rondom die feite, teken. Die leser se siening van byvoorbeeld die redes vir en gevolge van die optrede van karakters word grootliks gerig deur sy begrip van die omstandighede waaronder dit alles plaasvind. Veral sy emosionele betrokkenheid by die atmosfeer wat aan gebeure of karakters gekoppel word en waarbinne hulle optree, speel 'n belangrike rol in sy interpretasie.

Storieruimte is dus 'n sleutel tot die geskiedkundige oordeel wat die verteller in sy vertelteks ingebou het. Dit impliseer dat die literêre ondersoeker sorgvuldig dié tekens in die vertelteks wat dui op die omstandighede waaronder gebeure afspeel, moet dekodeer. Hieruit kan hy aflei hoe Tacitus daarin slaag om 'n spesifieke siening van die gebeure en karakters in te bou in sy vertelling daarvan, sonder om hierdie siening eksplisiet te verwoord. Dit is belangrik om 'n koherente beeld te probeer vorm van wat die oordeel is waartoe Tacitus sy lesers probeer lei.

In die meegaande analise word ondersoek hoe die organisasie van kleiner onderdele van die teks storieruimte konstitueer. Die werkwyse is hoofsaakdik tradisioneel filologies. Aandag word gegee aan byvoorbeeld woordkeuse en konnotasies van woorde, woordplasing en/of sinskonstruksie. Die terminologie wat gebruik word, is konvensioneel binne die klassieke filologie en het nie verdere omskrywing nodig nie. Die enigste verskil is dat hierdie faktore ondersoek word spesifiek met die oog op die konstruksie van die storieruimte, met ander woorde binne die raamwerk van die narratologie.

\section{3 'N ANALISE VAN ANNALES I.1}

I.1 is ' $\mathrm{n}$ proloog in die kleine. Dit is in sekere opsigte vergelykbaar met die voorwoord in 'n moderne teks, maar daar is ook uiters belangrike verskille. Hierdie openingshoofstuk van die Annales funksioneer soos ' $n$ voorwoord in die sin dat dit nie deel vorm van die primêre vertelling nie. Dit dui die titel van die werk aan en verwys kortliks na die agtergrond en die redes vir die keuse van die onderwerp.

I.1 word egter angebied as ' $n$ integrale deel van die Liber primus. Dit is heelwat anders as die moderne praktyk om die voorwoord as nie-integrale deel te publiseer. Daarom verskil 
To the average Roman reader the prologue was of secondary importance; but for the modern student of literature ... the importance of those prologues is paramount.

(Leeman 1973:169)

Veral as die moontlikheid van 'n mondelinge voordrag in gedagte gehou word, moet die openingsreëls beskou word as die plek waar die gehoor se nuuskierigheid geprikkel moes word, waar hulle ook 'n definitiewe (hoewel subtiele en nie-finale) aanduiding moes kry van hoe hulle dit wat volg, moet interpreteer.

Die passasie bevat, soos verwag, ' $\mathrm{n}$ aantal van die topoi wat tradisioneel in die proloẽ van antieke geskiedskrywing voorkom, naamlik die naam van die outeur; 'n opsomming van die voorafgaande geskiedenis (r.1-8); asook 'n implisiete uitspraak oor Tacitus se siening van die historiografie, vervat in sy uitsprake oor die stand van Romeinse geskiedskrywing (rr.8-14).7 Daar is ook inligting oor sy onderwerp: pauca de Augusto et extrema . . . mox Tiberii principatum et cetera.8 Die beroemde frase, sine ira et studio (rr.15-16), gee bykomende (implisiete) inligting oor Tacitus se idees in verband met geskiedskrywing. Hierdie inligting is egter onvolledig omdat dit een van die belangrikste aspekte van die topos heelternal weglaat, naamlik ' $n$ verwysing na die aard en veral na die belangrikheid van die stof wat hanteer gaan word. 9 Nogtans is $I .1$ as geheel uiters belangrik omdat dit die toon en atmosfeer asook die basiese temas vir I.1-15 inleidend daarstel.

I.1 kan onderverdeel word in drie kleiner vertelsegmente: die voorgeskiedenis van dominatio (rr.1-8), die huidige stand van die geskiedskrywing (rr.8-14) en die beoogde werkwyse van die verteller (rr.14-16). In die laaste twee reëls stop die vertellyn wat vanaf reël 1 tot by reël 14 verder gevoer is, terwyl die outeur inligting verskaf oor die manier waarop hy sy vertelling gaan inklee.

\section{(a) 'n Voorgeskiedenis van dominatio (I.1, rr.1-8)}

Die vertelling in reëls $1-8$ het ten doel om inligting oor te dra oor die tydperk wat die pauca de Augusto voorafgaan, dit wil sê om 'n algemene agtergrond te verskaf. Die verteller is oënskynlik slegs besig om sy leser in tyd te oriēnteer. By die sorgvuldige lees van die gedeelte, word dit egter duidelik dat hy reeds hier in die vertelteks 'n storieruimte konstitueer wat ' $n$ bepalende rol in die leser se konstruksie en interpretasie van die storievlak in die Annales as geheel sal speel.

7 Leeman (1973:170-171) som die gebruiklike topoi soos volg op: (1) inligting oor die outeur; (2) inligting oor die onderwerp, aard en belangrikheid daarvan; (3) inligting oor die outeur se benadering tot die onderwerp en sy beskouings oor historiografie in die algemeen; (4) inligting or die outeur se beskouinge oor geskiedenis; en (5) 'n opsomning van voorafgaande gebeure.

8 Hierdie inligting is minder volledig as wat die gebruik was.

9 Vgl. Classen (1986:7). 
Urbem Romam a principio reges habuere; libertatem

et consulatum L. Brutus instituit.

"Konings het aanvanklik die stad Rome beheer;

Lucius Brutus het die vrye konstitusie daargestel;

Die enigste verwysing na fisieke ruimte (een aspek van storieruimte) is urbem Romam $(\boldsymbol{r} .1)$, in 'n beklemtoonde posisie aan die begin van die hoofstuk.10 'n Mens hoef net die eerste sin te iees om te besef dat urbs Roma hier reeds verwys na die staatkundige konsep, eerder as na die geografiese lokaliteit, Roma. Die leser sou vir homself die storie bevredigend kon konstrueer sonder om 'n gedetailleerde beeld van die stad Rome te vorm. Die fisieke ruimte van urbs Roma speel nie 'n betekenisgewende of aktiewe rol in die verhaal nie. Wat wel betekenis bepaal, is die algemene klimaat of atmosfeer wat daar heers. Tacitus assosieer vanaf die eerste oomblikke van sy vertelling die verskillende tipes staatsopset elk met 'n spesifieke atmosfeer. Hierdie atmosfeer is net so 'n integrale deel van die ruimte waar hinne ciie karakters optree en die gebeure afspeel, as wat fisieke ruimte is.

Die woordkeuses in die sin Urbem Romam a principio reges habuere (r.1), lei die leser aanvanklik nie baie sterk om die politieke klimaat aan te voel nie, veral omdat hy in tyd ver verwyderd staan van hierdie opset.11 Die woord libertatem in die volgende sin libertatem et consulatum L. Brutus instituit ( $\pi .1-2)$, is 'n woord wat gewoonlik op alle mense in alle tydvakke emosioneel inwerk en waarskynlik ook vir die Romeine van Tacitus se tyd gelaai was. Hiermee word die leser subtiel betrokke gemaak by die staatkundige opset wat genoem word. Die emosionele klimaat verbonde aan die idee van litertas tree toe as betekenisgewende komponent in die verhaal. Dit veroorsaak dat daar nou spanning ervaar word in die jukstaponering van habuere en libertotem (r.1).

Die oordeel wat die leser maak oor die gebeure wat aan hom voorgehou word, word gerig deur sy konsep van die atmosfeer of ruimte waarin dit afgespeel het. Die staat van gebondenheid geassosieer met die eerste staatsbestel, urbem Romam . . . habuere, word negatief beoordeel. Die leser kry (waarskynlik onbewustelik en moontlik eers in retrospeksie) by die lees van die sin libertatem . . . instituit die gevoel van verligting wat saamhang met die loskom uit die gebonde atmosfeer en die corgang na 'n politieke klimaat van vryheid, wat aksiomaties met die republikeinse konstitusie verbind word.12

Die gewaarwordinge van die leser is beskryf met woorde soos "emosionele klimaat," "spanning", "staat van gebondenheid", "gebrek aan vryheid", "gevoel van verligting". Dié gewaarwordinge werk in op sy emosies. Hulle is ook teenwoordig wanneer hy in sy verbeelding die atmosfeer konstrueer waarbinne die gebeure en karakters van die storie

10 Daar kan dus wel onmiddellik in die verbeelding 'n fisieke ruimte gekonstrueer word waarbinne die gebeure wat vervolgens beskryf word, afspeel. Ho volledig die fisieke nuimte bewustelik of onbewustelik - deur die leser gekonstrueer word, hang van 'n groot aantal faktore af wat verband hou met sy eie kennis en vermoēns. Elke leser sal die fisieke ruimte tot 'n mindere of meerdere mate konstrueer, al is dit dan net omdat geen gebeurtenis anders voorgestel kan word as dat dit afspeel in die ruimte nie.

11 As aanvaar word dat die Annales in 115 of 116 n.C. voltooi is en dat die konings kort na die stigting van Rome in 753 v.C. an bewind gekom het, sou selfs die vroegste leser ten minste ongeveer 8 eeue na die gebeurtenis gelewe het.

12 Vgl. Leeman (1973:192): "Libertatem et consulatum links the Republican constitution and the concept of political liberty." 
optree. Dit is trouens juis deur die emosies van die leser subtiel by sy leesproses betrokke te maak, dat die verteller hom aanspoor om die storienimte meer volledig te konstrueer.

In die gedeelte dictaturae . . accepit (I.1, rr.2-8) lyk dit op die $\infty \mathrm{g}$ af asof die verteller die geskiedenis van republikeinse Rome teken as ' $n$ tydperk van vryheid wat by 'n antal geleenthede vir 'n kort periode onderbreek word:

dictaturae ad tempus su-

mebantur; neque decemviralis potestas ultra biennium neque tribunonm militum consulare ius diu valuit. non Cinnae, non Sullae longa dominatio; et Pompei Crassique potentia cito in Caesarem, Lepidi atque Antonii arma in Augustum cessere, qui cuncta discordiis civilibus fessa nomine principis sub imperium accepit.

\begin{abstract}
"diktatorskappe is by geleentheid opgeneem; die bevoegdhede van die decemviri was nie meer as twee jaar van krag nie en ook die bewind van militêre offisiere was van korte duur. Nog Cinna, nóg Sulla se alleenheerskappy was lank uitgerek; beide Pompeius en Crassus se invloed en Lepidus en Antonius se leërs het gou in die hande van Caesar en Augustus onderskeidelik beland. Laasgenoemde het met die titel 'princeps' die bevel geneem oor die hele staat, uitgeput van burgeroorloē."
\end{abstract}

Die kortstondigheid van die onderbrekings word sorgvuldig aangedui: ad tempus (r.2), neque . . ultra biennium (r.3), neque ... diu ( $\mathrm{rr} .3-4)$; non longa ( $\mathrm{rr} .4-5)$ en cito (r.6). Nogtans maak elke onderbreking groter inbreuk op die libertas en is dit verder verwyderd van die republikeinse ideaal as die vorige. Eerstens is daar die konstitusionele dictaturae (r.2), decemviralis potestas (r.3) en tribunorwn militum consulare ius (r.4). Hierna volg die opbou na 'n klimaks via dominatio en potentia (rr.5-6) tot by arma (r.6). By non Cinnae, non Sullae longa dominatio ( $\pi .4-5)$ is daar 'n subtiele wending te bespeur. Die onderbreking van die vryheid word grammatikaal soos in die vorige sin met 'n negatiewe stelwyse aangedui: non longa. Die wending is egter gelee in die woord dominatio wat onkonstitusionele optrede suggereer, asook in die feit dat die verteller die leiers van hier af by name noem, en nie meer hulle konstitusionele ampte aandui nie.

Die voortsetting van die gedagtegang met $e t$. . cito, laat dit vir 'n comblik klink asof ook die leierskap van die twee triumvirate (Pompeius, Crassus en Caesar, asook Lepidus, Antonius en Augustus) verdere kortstondige (hoewel onkonstitusionele) onderbrekings in die libertas verteenwoordig het. Dan eers kom die besef dat die twee parallelle frases (in Caesarem en in Augustum, $\pi .6-7$ ) in werklikheid aandui hoe die mag telkens van een outokratiese leier (of groep leiers) na 'n volgende oorgeplaas word en dat dit nié, soos telkens vroeĕr, na die volk terugkeer nie.13 Die implikasie hiervan vir die storieruimte wat geskep word, is dus dat die klimaat of atmosfeer van vryheid, byna direk nadat dit gestel is, weer geleidelik verdring word deur een van onderdrukking. Die storieruimte waarbinne die gebeure in die deel van die proloog plaasvind, kan dus beskryf word as 'n atmosfeer van (toenemende) inhibering of gebondenheid.

Daar is nog ' $n$ belangrike aspek van die gedeelte in reëls 2-8 wat aangeroer moet word. Tacitus moes uiters selektief te werk gaan om in slegs 'n paar reëls 'n oorsig oor die Romeinse geskiedenis, vanaf die koningstyd tot by die tyd van Augustus, te kan weergee. libertas became chronic by 60 B.C., and that both triumvirates, begun as a shared and thereby tempered dominatio, quickly (cito) developed into monarchies - not a mere continuation, but an intensification of the process." 
Die koningstyd word bloot aangedui. Oor republikeinse Rome is daar 'n paar gegewens. Tacitus, na wie algemeen verwys word as die geskiedskrywer met 'n groot nostalgie na die tyd van die Republiek,14 noem egter nie die gevierde vryheid van spraak, of die aequalitas, of enige van die positiewe aspekte van hierdie regeringsvorm nie. Hy kies slegs een aspek om op te konsentreer: tye van krisis wanneer die republikeinse konstitusie tydelik 'n meer outokratiese regeringsvorm toegelaat het: "an enumeration of instances of dominatio or absolute power even under the Republic" (Leeman 1973:192). Hy kies dit wat die saadjie vir die ondergang van die republiek bevat het, en toon in een netjiese lyn hoe dit tot sy onvermydelike uiteinde ontwikkel het: die prinsipaat van Augustus.

Tacitus som hier nie alleen die tydperk voorafgaande aan die behandel in die Annales op nie, maar dui ook doelbewus die werklike tema van sy geskiedskrywing aan. Dit doen hy wel besonder subtiel. Die negatiewe stelwyse wat hy vanaf reël 3 gebruik (neque ... neque; non ... non; et . . . cito) laat dit klink asof hy die onderbrekings in die libertas geringskat, asof dit nié is waarop hy in hierdie tydperk wil konsentreer nie. En tog is dit juis wat hy doen. Die tema van die Annales is dus aangekondig: dominatio. 15 Terselfdertyd konstitueer hy 'n spesifieke storieruimte rondom hierdie begrip: een gekenmerk deur 'n totale verlies aan die libertas wat die integrale bestanddeel van die republikeinse konstitusie gevorm het.

Daar is ook 'n ander belangrike sleutel tot die begrip van die Annales waarvoor die leser hier moet oplet. Tacitus se oordeel is nie te vinde op die oppervlak van sy vertelling nie.16 Dit moet gesoek word in die subtiele ondertoon wat daargestel word. 'n Belangrike aspek van hierdie ondertoon is die storieruimte wat uit kodes in die teks gekonstrueer kan word, en wat die leser se oordeel oor die karakters en gebeure rig.

Die bysin qui cuncta discordiis civilibus fessa nomine principis sub imperium accepit (rr.78), beskryf Augustus se aksies: "in a kind of ritardando, these words mark the final stage the principate" (Leeman 1973:194). Dit is nog 'n illustrasie van hoe Tacitus, selfs in so 'n kort opsomming soos hierdie, aan meer as slegs feite aandag gee. Die feit van discordiis civilibus kon hy op neutrale wyse as opsomming van die voorafgaande weergegee het. Deur die invoeging van én woord, fessa (r.7), met discordiis civilibus as die redegewende ablatief dárby, skep hy egter 'n emosionele klimaat waarmee enige leser onmiddellik kan (en daarom waarskynlik sal) identifiseer. Die leser neem nou nie net die feite van die reeks krisisse wat in die voorafgaande opgenoem is, intellektueel waar nie. Hy word ook gedwing om die politieke atmosfeer wat hiermee gepaard gegaan het, aan te voel. Hy word met ander woorde aangespoor om in sy verbeelding ' $n$ spesifieke storieruimte te konstrueer teen die agtergrond waarvan hy die gebeure en karakters wat Tacitus hier en later aan hom voorhou, beoordeel. Die atmosfeer van cuncta fessa maak dit byvoorbeeld makdiker om te verstaan hoe (volgens die oordeel van die verteller) dit moontlik was vir Augustus om juis nou - nadat niemand dit in die verlede suksesvol kon doen nie - die mag finaal en met die goedkeuring van die volk in homself te konsolideer. Daar word ook geen twyfel gelaat oor hoe die verteller die bewind van Augustus wil voorstel nie: dit is die klimaks in 'n reeks diktature.

Daar is navorsers wat sê dat Tacitus hom hoofsaaklik besig hou met karakters, met die mens en hoe hy deur sekere politieke omstandighede geaffekteer word. In samehang

14 Vgl. bv. Koestermann (1963-1968:36) en Flach (1973:224).

15 Vir die negatiewe konnotasies van hierdie woord, vgl. bv. Koestermann (1963-1968:66) of Goodyear (1972:108).

16 Vgl. Ceausescu (1974:191): "Die betekenis van die passasies blyk nie by die eerste lees daarvan nie" (vry vertaal). 
hiermee word dan gesê dat Tacitus nie die regeringsvorm van die prinsipaat as sodanig afkeur nie, maar slegs die persoon van die leier wat telkens sy posisie misbruik.17 Dit wat hier angedui word as die tema van die Annales (naamlik dominatio) maak dit duidelik dat bogemelde siening nie aanvaar word nie. Tacitus maak juis die regeringsvorm die onderwerp van sy geskiedskrywing. 18

\section{(b) Die huidige stand van historia (I.1, rr.8-14)}

8

10 sed veteris populi Romani

prospera vel adversa claris scriptoribus memorata sunt, temporibusque Augusti dicendis non defuere decora ingenia, donec gliscente adulatione deterrerentur: Tiberii Gaique et Claudii ac Neronis res florentibus ipsis ob metum falsae, postquarn occiderant recentibus odiis compositae sunt.

"Maar die vroeëre wel en wee van die Romeinse volk is deur bekwame skrywers opgeteken en daar was nie 'n tekort aan groot geeste om die tydperk van Augustus te beskryf nie totdat hulle hulle toenemend aan vleitaal begin skuldig maak het. Die situasie onder Tiberius en Gaius en ook onder Claudius en Nero is tydens hulle lewe uit vrees - en na hulle dood uit vars wrokkigheid - vals weergegee."

In reëls 8-14 gee Tacitus 'n oorsig oor die vroeëre historiografie. Hy spreek 'n oordeel uit, eers in terme van twee tydperke in die geskiedskrywing: die tyd vór Augustus en die tydperk aan die begin van Augustus se bewind. Sy oordeel oor die geskiedskrywing tot en met die tyd van Augustus is positief: claris scriptoribus (r.9); decora ingenia (rr.10-11). 'n Proses van agteruitgang tree egter gedurende die laaste deel van Augustus se bewind in. Die oorsaak vir hierdie agteruitgang in die historiografie geld ook vir die vierde tydperk waaroor Tacitus 'n oordeel uitspreek: Tiberii Gaique et Claudii ac Neronis res florentibus ipsis (r.11-12).19 Dit word aangedui met die terme gliscente adulatione (r.11); ob metum (r.12); en recentibus adiis (r.13). Al drie hierdie stelle terminologie dui op die bestaan van 'n ongesonde situasie, 'n atmosfeer waarin vleiery, valsheid, vrees en haat seēvier. Die leser wat die implikasies van reëls 1-8 ingesien het, aanvaar die toestand van die geskiedskrywing en die atmosfeer hier geredelik as die logiese gevolg van dit wat daaraan voorafgegaan het. Dit dra ook by om die storieruimte, aangedui in die vorige gedeelte, te bevestig.

17 Vgl. bv. Shotter (1967:158-159): "But is not he less interested in constitutional power than in the personal situations ... to which the principate, with Tiberius, Claudius, or Nero as princeps, gave rise?"; Vogel-Weidemann (1979:102) asook Percival (1980:121): "It quickly becomes clear that we must abandon the idea that Tacitus objected to the Principate as such, that is, that he thought it was necessarily and by definition a dominatio, without any possibility of being anything else. In other words, he was attacking bad princijes rather than the Principate itself."

18 Vgl. Leeman (1973:197): "In the Annals he is concerned with dominasio, even under the Republic" en "The same theme - dominatio gradually crushing libertas - is at the basis of the following chapters. "

19 Die vier "tydperke" is dus: (i) voor die tyd van Augustus, (ii) die eerste gedeelte van Augustus se bewind, (iii) die laaste deel van Augustus se bewind, en (iv) die tyd na Augustus. 
Terselfdertyd stel hierdie passasie die belangrikste temas van die werk aan die orde: die subtemas vrees (metum, r.12) en valsheid (falsae, r.13) asook adulatio (r.11) en servitium (die keerkant van adulatio en geïmpliseer deur falsae, r.13) is teenwoordig in die sin waar Tacitus die redes vir die swak geskiedskrywing onder die prinsipaat verskaf. Die hooftema van I.1-15, naamlik dominatio as die ware aard van die prinsipaat, is hier (soos in die voorafgaande reëls) implisiet teenwoordig.

\title{
(c) Beoogde werkwyse (I.1, rr.14-10)
}

14

inde consilium mihi pauca de Augusto et extrema

tradere, mox Tiberii principatum et cetera, sine ira et studio, quorum causas procul habeo.

\begin{abstract}
"Vandaar my plan om 'n paar feite oor Augustus en oor sy laaste dae te verskaf en daarna die prinsipaat onder Tiberius en die ander te beskryf sonder woede en sonder gedienstigheid. Want ek staan ver verwyderd van die oorsake daarvan."
\end{abstract}

In die laaste drie reëls onderbreek Tacitus sy vertelling van gebeure om inligting oor sy onderwerp te verstrek. Op die $\infty \mathrm{g}$ af lyk dit asof 'n belangrike aspek van hierdie topos (die aard of belangrikheid van die stof) weggelaat is. Bogenoemde analise toon egter dat die leser wat al die nuanses van die voorafgaande vertelling waargeneem het, 'n goeie aanduiding het van dit wat die verteller oor die aard van sy stof dink. Vir hom behoort die gebeure wat hy beskryf tot 'n tydperk van gebondenheid waar libertas vernietig is. Hy het aangedui hoe hierdie toestand ontstaan het en dat dit voortduur tot in die tyd van Tiberius, Gaius, Claudius en Nero. Hy skryf dus oor 'n era wat begin op dié tydstip toe die libertes tot so 'n mate verlore gegaan het dat dit geskiedskrywing begin inhibeer het. Hy kan egter, omdat hy ver genoeg van die tydperk verwyder staan om nie meer so geïnhibeer te word nie, sine ira (dit wil sê sonder recentia odia) en sine studio (dit wil sê sonder adulatio en die metus wat dit veroorsaak) daaroor skryf.

Die frase sine ira et studio (rr.15-16) is dié gedeelte in die Annales wat navorsers op 'n dwaalspoor gelei het, omdat dit geinnterpreteer is as 'n verbintenis tot objektiewe geskiedskrywing in die moderne sin van die woord. 'n Soortgelyke verklaring ten opsigte van onpartydigheid in 'n proloog was teen die tyd toe Tacitus geskryf het reeds 'n gemeenplaas. 20 Dit moet daarom geëvalueer word binne die raamwerk van hoe topoi in antieke letterkundige genres hanteer is en nie op gesigswaarde nie.21 In hierdie geval dui die frase aan dat die verteller los staan van die onmiddellike invloed van die keisers oor wie hy skryf. Die implikasie is dat die oordeel waartoe hy lesers lei, gebaseer is op intellektuele insig in die gebeure en karakters en nié op die tipe emosionele reaksies wat hy in sy voorgangers bespeur nie. Dit impliseer nie dat hy nie die leser se emosies gaan aanspreek in die manier waarop hy sy intellektuele insig oordra nie. Dit sou immers 'n radikale afwyking van alle retoriese beginsels beteken.

En die leser se emosies word veral aangespreek deur middel van die storieruimte wat Tacitus op 'n subtiele wyse in die vertelteks daarstel. Die belangrikste subtemas van Annales 1.1-15 kan trouens juis beskou word as aspekte van die storieruimte: die staatsbestel, wat deur dominatio gekenmerk word, gee aanleiding tot 'n atmosfeer van vrees wat weer op sy beurt aanleiding gee tot die ander subtemas (valsheid, adulatio en

$20 \mathrm{Vgl}$. in hierdie opsig veral Luce (1989:16).

21 Oor die ware betekenis van hierdie frase is baie geskryf. Die artikels van Cizek (1979) en Luce (1989) gee 'n gceie oorsig oor die verskillende aspekte van die saak. 
servitium). Binne hierdie storieruimte word gebeure en karakters anders beoordeel as wat hulle daarsonder beoordeel sou word.

\section{SLOTOPMERKING}

Bied die narratologie 'n geskikte invalshoek vir 'n analise van Tacitus se Annales? Kan so 'n analise 'n bydrae lewer tot 'n beter begrip van Tacitus as geskiedskrywer? Hierdie vrae kan myns insiens op grond van bostaande bespreking ten minste gedeeltelik positief beantwoord word. Eerstens bied die narratologiese onderskeiding tussen die vier vlakke van ' $n$ verhalende teks 'n besonder geskikte stel terminologie aan die hand waarvan omskryf kan word wat antieke geskiedskrywing is, en wat dit nie is nie. Hierdie invalshoek bied 'n raamwerk waarbinne die aard van die teks en die doel van die analise omskryf kan word op 'n wyse wat besware soos dié van Wellesley uitskakel.

Die vraag oor die bydrae wat 'n narratologiese analise tot 'n beter begrip van Tacitus se werk kan lewer, kan nie nou finaal beantwoord word nie. Dit sal eers moontlik wees wanneer groter teksgedeeltes aan die hand van meer van die talle ander narratologiese kategorieë (byvoorbeeld die optrede van die verteller, die volgorde en ritme van die vertelling, ensovoorts) ondersoek is. Bostaande analise toon egter reeds hoe raak daardie ontwykende kwaliteit van Tacitus se geskiedskrywing, die veelbesproke "innuendo" of "insidious suggestion", aan die hand van die narratologie omskryf kan word. 22 In Annales I.1 is dit hoofsaaklik dié elemente in die vertelteks wat die leser lei om die storieruimte te konstrueer en die wisselwerking tussen storieruimte, gebeure en karakters wat Tacitus se opinie oor die gebeure weerspieël, en wat met ander woorde die "innuendo" daarstel.

\section{BIBLIOGRAFIE}

Aubrion, E. 1985. Rhétorique et histoire chez Tacite. Metz: Centre du Recherche "Littérature et Spiritualite" de l'Univ. de Metz.

Bal, M. 1978. De theorie van vertellen en verhalen. Inleiding in de narratologie. Muiderberg: Coutinho.

Brink, A.P. 1987. Vertelkunde. 'n Inleiding tot die lees van verhalende tekste. Kaapstad: Academica.

Ceausescu, P. 1974. "L'image d'Auguste chez Tacite." KIio 56, 183-198.

Cizek, E. 1979. "Sine ira et studio et l'image de l'homme chez Tacite." Studii Clasice 18, 103-113.

Classen, C.J. 1986. "Zum Anfang der Annalen des Tacitus." Der altsprachliche Unterricht 29 no. 4, 4-15.

Develin, R. 1983. "Tacitus and techniques of insidious suggestion." Antichthon 17, 64-95.

Genette, G. 1982. Figures of literary discourse. Vertaal deur A. Sheridan. New York: Columbia University Press.

Goodyear, F.R.D. 1972. The Annals of Tacitus. Books 1-6. vol. I, Cambridge Classical Texts and Commentaries, ed. C.O. Brink, D.W. Lucas and F.H. Sandbach. Cambridge: University Press. 
Heubner, H. 1983. P. Cornelii Taciti libri qui supersunt I, Ab excessu divi Augusti. Bibliotheca scriptorum Graecorum et Romanorum Teubneriana. Stuttgart: Teubner.

Koestermann, E. 1963-1968. Cornelius Tacitus. Annalen. 4 vols. Wissenschaftliche Kommentare zu Griechischen und Lateinischen Schriftstellern. Heidelberg: Carl Winter Universitătsverlag.

Kotzé, A. 1990. Tacitus se Annales 1.1-15. 'n Vertelkundige analise. Ongepubliseerde M.A.tesis, Stellenbosch.

Leeman, A.D. 1973. "Structure and meaning in the prologues of Tacitus." Yale Classical Studies 23, 169-208.

Luce, T.J. 1989. "Ancient views on the causes of bias in historical writing." Classical Philology 84(1), 16-31.

Percival, J. 1980. "Tacitus and the principate." Greece and Rome 26, 119-133.

Prince, G. 1982. Narratology. The form and functioning of narrative. Janua linguarum, . Series Maior 108, ed. C.H. van Schooneveld. New York: Mouton Publishers.

Rimmon-Kenan, S. 1983. Narrative fiction. Contemporary poetics. New Accents, ed. T. Hawkes. London: Methuen.

Ryberg, I.S. 1942. "Tacitus' art of innuendo." Transactions and Proceedings of the American Philological Association 73, 383-404.

Schillinger-Häfele, V. 1966. "Zum Annalen-proomium." Hermes 94, 496-500.

Shotter, D.C.A. 1967. "Tacitus Annals I.13." Classical Philology 62(1), 37-39.

Vogel-Weidemann, U. 1979. "The opposition under the early Caesars. Some remarks on its nature and aims." Acta Classica 22, 91-107.

Wellesley, K. 1987. Resensie van Rhétorique et histoire chez Tacite, deur E. Aubrion. In Gnomon 59, 450. 